\title{
Implementation of Appropriate Marketing and Sales Strategies in Improving Company Performance and Profits
}

\author{
Finny Redjeki ${ }^{1}$, Haris Fauzi ${ }^{2}$, Sidik Priadana ${ }^{3}$ \\ ${ }^{1}$ Universitas Sangga Buana, Bandung, Indonesia \\ ${ }^{2}$ Universitas Majalengka, Indonesia \\ ${ }^{3}$ Universitas Pasundan, Bandung, Indonesia \\ Email: finnyredjeki@usbypkp.ac.id
}

\begin{abstract}
Every company has a goal of getting a specific profit or as much as possible and maintaining or even trying to increase it for the long term. This goal can be realized if the sale can be carried out as planned. Thus it does not mean that the goods or services sold will always generate profits, so the above factors must receive full attention for the company. Superior competence in understanding customers and, therefore, the opportunity to provide satisfaction to customers and the ability to recognize competitors' movements. Companies that manage to control the market and this arena are called market-driven firms that balance these two orientations well to produce better marketing performance than companies with other directions. Coordination between the company's functions as an effort, for example, to share information about customers and competitors with all tasks better to face the growing competition from time to time.
\end{abstract}

Keywords: Company, Marketing Performance, Marketing Concept, Sales Concept, Marketing Mix.

\section{A. INTRODUCTION}

Today, product marketing is increasingly intense, including consumer goods and industrial goods and services (Mcdonald et al., 2001). This competition is mainly found in buyers' market conditions, where buyers have a dominant role in the market (Dobson et al., 2001). In this case, the buyer is considered a king, who must be served and satisfied with the goods or services purchased. By emphasizing providing satisfaction to consumers, there is a shift in the concept of an approach in product marketing from a sales concept to a marketing concept (Christy et al., 1996).

Marketing activities for a company are one of the main activities that a company must carry out to maintain its survival. Companies must consider so many factors in carrying out marketing activities for products produced for companies that make products and companies that specifically sell products (Porter, 1980).

The rivalry level between business sectors is rising in today's business world, including companies in Indonesia. With the advent of technology in this globalization period, every business aims to constantly increase the efficiency of manufacturing and marketing management to optimize benefits according to the intention sought by each company (Gunawan \& Wahyuni, 2014). Increased rivalry in the corporate world has permeated all business sectors (business), making current competition between firms more complex. Companies in the goods and services 
industry cannot be isolated from this rivalry, in which an organization must be able to face multiple challenges that occur in handling its selling business, as well as ensuring that the company involved can work with effective and productive management (Assih \& Hastuti, 2014).

Each corporation will boost retail prices by using an aggressive marketing system and unique strategies for expanding the current customer market. Marketing strategy is a marketing mix strategy, which includes Price, Product, Promotion, and Places (Ohy, 2010). Marketing is a vital role of a corporation since it defines its (product's) sales volume and market position (Keith, 1960). Mastery of market share depends on taking advantage of its marketing strategies, such as: how to promote a product price, how the pricing strategy with existing competitors, how the promotion policy, how is the proper distribution process, and how to know the market environment and so on (Bhide, 1994).

The level and types of needs and desires of consumers can differ from one another, which causes the choice of opening a business opportunity to be more numerous and more significant, the reasons for choosing or the purpose of selecting and the factors that must be considered in an attempt to do business for each consumer as well. Besides, determining which segment of the market is located, identifying consumers into specific details, and identifying what targets were achieved and positioning.

\section{B. METHOD}

In this study, the authors used qualitative research. According to Creswell: "qualitative research is a method for exploring and understanding the meaning that a number of individuals or a group of people think comes from a social or human problem." The researcher's study will focus on a social and complex problem. As a result, the researcher decided to use qualitative analysis techniques to assess how to locate, obtain, store, and interpret research results (Creswell, 2016).

Qualitative research is research that uses many methods, interpretive and naturalistic approaches, observes objects in a natural setting, seeks to interpret or interpret phenomena from the perspective of the community involving the use of numerous research resources extracted from case studies, personal interactions, introspection, life stories, interviews, interpretation, factual, interactional, and visual texts to explain routine and troublesome moments and meanings in an individual's life (Semiawan, 2010).

\section{RESULT AND DISCUSSION}

\section{Marketing Management and Its Development}

The made marketing decisions certainly influence the company's efforts to achieve goals and maintain and develop them. Marketing decision-making is almost always related to the marketing mix variables (Sukotjo \& Radix, 2010). Therefore, this marketing mix is essential and can be used as a practical marketing tool. 
The demand exerts the most pressure on the brand mix since its goods are ultimately aimed at the consumer. This market need is used as the basis for determining the types of products and the market conditions for various alternative prices, promotions, and distribution. This problem shows companies allocate their marketing activities to each of the mixed variables (Bowman \& Gatignon, 1996).

Discussion of a theoretical review of the marketing mix will begin with the concept or understanding of marketing, marketing mix strategy, the relationship between price decisions, promotion and distribution, and various aspects of the company's marketing mix.

Knowledge and skills in marketing are essential in business activities. But more important than that is what is called here with the concept of marketing. The marketing concept is nothing but a philosophical foundation that directs action in the marketing field. This is a logical continuation of the historical development of the companies. Previously, the firm has several different orientations, such as manufacturing orientation. The manufacturing method is the focal point here, with others acting as complements. The time when the business is financially focused is also established. During this time, the financial role took charge. Then, the company's orientation is to deliver as many products as possible that have been made. The marketing orientation is the following sign in this company's direction that can be observed. The central point here is marketing. In a situation where the competition is getting fierce, the concept directed at this marketing orientation is known as the marketing concept (Houston, 1986).

\section{Sales Concept}

In the business world, various activities from the type of business (manufacturing) that produce goods, trading businesses that distribute merchandise, and service businesses, will ultimately lead to selling goods or services. Sales activity is a determination in the business world. With these sales activities, the company will receive a reimbursement equal to the price of the goods or services agreed upon when the sale and purchase are carried out. From these sales activities, the seller expects that the goods or services will again be at a price point whose value is higher than the cost of goods (cost) so that the company will earn a profit. To achieve the maximum level of profit, the sales manager must see and observe the existing market conditions. Thus, the sales manager can see the opportunities that exist in the market. The following is sales management definition, namely planning, directing, and monitoring personal selling, including withdrawal, selection, equipment, route determination, supervision, payment, and motivation as tasks assigned to salespeople (Firmansyah, 2019).

From the above understanding that sales management is known that the sales manager's duties are pretty broad. It can also be said that the sales manager's job is as an administrator in personal selling activities so that the main task has a lot to do with sales personnel. Another part and duties of the sales manager are organizing sales activities both within the company and outside the company. He must compile 
an organizational structure that can create effective communication within the sales department and other existing departments. Within the company, and is also the most critical link between the company and consumers or buyers and other communities, is responsible for creating and maintaining an effective distribution network. Apart from these tasks, the sales manager still has different tasks, namely using and participating in preparing information for marketing decision-making, such as determining budgets, quotas, and sales areas, and participating in making decisions about products, marketing channels, or distribution politics promotion. And price mapping (Stewart, 2005).

So it can be said that the sales manager is apart from being an administrator of personal selling activities and a member of a group of managers who take part in marketing decisions. Success can be achieved when someone has a goal or hope, as well as entrepreneurs or salespeople. These goals will become a reality if implemented with sufficient willingness and ability (Stewart, 2005). Apart from that, the following factors must also be considered.

a. Capital required

b. Ability to plan and make products,

c. Ability to determine the right price level

d. Ability to select the right supplier

e. Ability to use appropriate promotional methods.

In general, entrepreneurs have a goal of getting a specific profit or as much as possible and maintaining or even trying to increase it for the long term. This goal can be realized if the sale can be carried out as planned. Thus, it does not mean that the goods or services sold will always generate profits; this is where the above factors must receive the company's full attention for companies, generally have three general goals (Umar, 2002), as follows

a. Reach a specific sales volume.

b. Getting a sure profit.

c. Supporting company growth.

Sales executors or salespeople do not solely carry out efforts to achieve these three objectives. In this case, there must be neat cooperation between functionaries in the company and with the distributors. In practice, sales activities can be influenced by several factors. The factors are as follows.

a. Conditions and sales capabilities

b. Existing market conditions

c. The amount of capital used.

d. The condition of the company organization

e. Other factors that can affect sales.

With the advent of the industrial revolution, companies succeeded in making goods on a large scale. Previously produced by hand, machines carried out the production process at the beginning of the Industrial Revolution. The main problem faced in this phase is how to sell these items. Making good things alone is not sufficient to guarantee the success of a company. The company's work is measured 
primarily by the volume of sales it produces. Sales-oriented companies like this are said to adhere to a concept called sales (Shinta, 2011).

Companies that adhere to the concept of sales are more concerned with sales than customer satisfaction. Sellers would not hesitate to use less truthful approaches (promotions) to convince buyers to purchase. These strategies will ultimately damage the business, so many consumers will be frustrated if what the vendor said about the products they ordered does not meet it.

These customers will feel betrayed and will not make another order, so subscriptions will not be formed. The selling concept is mainly carried out on products that are not good or products usually not thought of by buyers, such as insurance, encyclopedias, etc.

\section{Marketing Concept}

Marketing is a marketing mix strategy system, and the marketing strategy itself is a subsystem of the marketing management process. Thus, the marketing strategy occupies a different position in marketing science but becomes an integral part of the overall marketing mix strategy. The marketing strategy can be explained by starting with how the organization produces a combination of deals that include goods, services, and costs and uses a promotional mix that provides for sales incentives, advertisement, salesforce, public relations, direct mail, and telemarketing to reach out end consumers and delivery networks. Product planning involves policies and procedures related to:

a. Types of products offered: quality, design, and so on.

b. The selling market: to whom, where, when, and for how much.

c. New product policy: research and development program

Pricing involves policies and procedures relating to:

a. The price level used.

b. The special price used.

c. Price policy, one price or one price range, efforts to maintain prices, and so on

d. The boundaries are used for companies and trade.

Distribution channels regarding policies and procedures relating to:

a. The channel used between factories and consumers

b. The level of selectivity between sellers and retailers

c. Efforts to get customer cooperation.

Promotion of Policies and Procedures Relating to:

a. Charges imposed on unique sales plans or equipment directed at or through trade.

b. Forms of consumer promotion tools for trade promotions.

The marketing concept has been formulated in various styles, such as "Find the desire and fulfill it." "Make what you can sell instead of trying to sell what you can make," and so on. Sales concepts and marketing concepts are often confused.

The concept of selling starts with existing products. Then there were massive sales and promotions to achieve profitable sales. The marketing concept begins with 
the target buyers' wishes and desires. All events that can provide customer loyalty are integrated and coordinated by the organization. Profits are produced by building and retaining customer loyalty.

In short, the marketing concept is oriented to the needs and desires of consumers supported by an integrated marketing effort, which is directed at creating customer satisfaction as the key to achieving company goals.

According to Putri (2017), the marketing concept agency requires us to pay attention to three things: consumers, coordination of marketing activities, and consumer satisfaction. This concept encourages us to look outside, namely consumers, and not into goods. This concept is often reflected in the saying that the consumer is king. Such an idea is often only interpreted as pleasing the buyer in buying and selling transactions. This is, of course, wrong.

As taught by the marketing concept, consumer-oriented requires entrepreneurs to do things that are more than pleasing to consumers. This often means an effort to study the functions and uses of the goods being produced carefully so that the goods to be marketed will suit consumers' needs and desires. Besides, different groups of consumers often have different needs. Finding groups whose needs are not yet fulfilled by the market is an essential task in this consumer orientation. Thus, consumer research is also necessary to discover the characteristics and consumption patterns of the consumer population.

Marketing that looks outward and into the future requires coordination and integration of marketing activities and the marketing mix in the form of a sales concept starting from existing products. Then there were massive sales and promotions to achieve profitable sales. The marketing concept begins with the target buyers' wishes and desires. All events that can provide customer loyalty are integrated and coordinated by the organization. Profits are produced by building and retaining customer loyalty.

In short, the marketing concept is oriented to the needs and desires of consumers supported by an integrated marketing effort, which is directed at creating customer satisfaction as the key to achieving company goals.

According to Hery (2019), the marketing concept agency requires that we pay attention to three things: consumers, coordination of marketing activities, and consumer satisfaction. This concept encourages us to look outside, namely consumers, and not into goods. This concept is often reflected in the saying that the consumer is king. Such an idea is often only interpreted as pleasing the buyer in buying and selling transactions. This is, of course, wrong.

As taught by the marketing concept, consumer-oriented requires entrepreneurs to do things that are more than pleasing to consumers. This often means an effort to study the functions and uses of the goods being produced carefully so that the goods to be marketed will suit consumers' needs and desires. Besides, different groups of consumers often have different needs. Finding groups whose needs are not yet fulfilled by the market is an essential task in this consumer orientation. Thus, it is also necessary that consumer research's role is as a tool to 
discover the characteristics and consumption patterns of consumers (Kotler \& Keller, 2006).

Marketing that looks to the outside and into the future requires coordination and integration of marketing activities and the marketing mix in the form of policies in the fields of goods, prices, distribution, and promotion. This coordination is essential if goals are to be achieved more effectively. Goods policy, for example, must be in line with price policies and aspects of distribution and promotion.

Incompatibility not only causes waste but more so because the achievement of targets may not be optimal. On the other hand, coordination is not something that will happen automatically but must be continuously worked on and developed. This coordination in large companies is reflected in the organizational structure, while in other companies, this may not be easy to see. Whatever the size of a company, if it effectively achieves its goals, it requires coordination and often the integration of marketing activities.

The third milestone of this marketing attitude is customer satisfaction. Customer satisfaction is not meant here, of course, only temporary pseudo satisfaction. More than that, the satisfaction referred to here is the ability to solve problems faced by consumers. Satisfied consumers are essentially consumers who have been able to solve problems or problem needs. (And it is this kind of satisfaction that will ensure the continuity of the company's operations because they are usually the ones who will become loyal customers.

\section{CONCLUSION}

In marketing and sales policies, the company seeks to apply various marketing mix variables to optimize product sales. The selling price of a product generally must be determined to be higher than the production price and other costs to make a profit. The existence of profits earned continuously will enlarge the business scale and continue to invest in the development of the company, which is what is being done. Marketing of products is generally domestic and foreign; at this time, competition conditions in the industry are very tight. Strategies for managing market operations that are aimed at increasing sales or securing hegemony of the market portion, dealing with competitor maneuvers or preventing the entry of new competitors,

To increase sales volume through the development of a product differentiation strategy or a product diversification strategy. One of the issues in developing a product mix strategy is the expansion of the number of product lines (product line breadth) as an effort to win the competition. Competition is described as a system of relationships in which companies can only exist and survive if they have unique advantages over their opponents. Suppose they do not have a special gift. In that case, the competition can shift its strategic position. Therefore, the more similar a company's strategic profile is to its closest competitors, the tougher market competition occurs. The company can develop its unique marketing and sales 
through product, price, promotion, and distribution. The market share can be maintained and even increased through it, not vice versa as a competitor.

\section{REFERENCES}

1. Assih, P., \& Hastuti, A. W. (2014). Pengaruh Manajemen Laba pada Nilai dan Kinerja Perusahaan. Jurnal Akuntansi dan Keuangan Indonesia, 2(2), 125-144.

2. Bhide, A. (1994). How Entrepreneurs Craft Strategies That Work. Harvard Business Review, 72(2), 150-161.

3. Bowman, D., \& Gatignon, H. (1996). Order of Entry as a Moderator of the Effect of the Marketing Mix on Market Share. Marketing Science, 15(3), 222-242.

4. Christy, R., Oliver, G., \& Penn, J. (1996). Relationship Marketing in Consumer Markets. Journal of Marketing Management, 12(1-3), 175-187.

5. Creswell, J. W. (2016). Research Design: Pendekatan Metode Kualitatif, Kuantitatif, Dan Campuran. Yogyakarta: Pustaka Pelajar.

6. Dobson, P. W., Clarke, R., Davies, S., \& Waterson, M. (2001). Buyer Power and Its Impact on Competition in the Food Retail Distribution Sector of the European Union. Journal of Industry, Competition, and Trade, 1(3), 247-281.

7. Espejel, J., Fandos, C., \& Flavian, C. (2008). Consumer Satisfaction. British Food Journal.

8. Firmansyah, M. A. (2019). Pemasaran: Dasar dan Konsep. Jakarta: Qiara Media.

9. Hery, S. E. (2019). Manajemen Pemasaran. Gramedia Widiasarana Indonesia.

10. Houston, F. S. (1986). The Marketing Concept: What it is and what it is not. Journal of Marketing, 50(2), 81-87.

11. Keith, R. J. (1960). The Marketing Revolution. Journal of Marketing, 24(3), 35-38.

12. Kotler, P., \& Keller, K. L. (2006). Marketing Management 12e. France: Edition Pearson Education.

13. McDonald, M. H., De Chernatony, L., \& Harris, F. (2001). Corporate Marketing and Service Brands-Moving beyond the Fast-Moving Consumer Goods Model. European Journal of Marketing.

14. Ohy, I. J. (2010). Masih Relevankah Strategi Marketing Mix Meningkatkan Kepuasan Pelanggan?. JDM (Jurnal Dinamika Manajemen), 1(2).

15. Porter, M. E. (1980). Industry Structure and Competitive Strategy: Keys to Profitability. Financial Analysts Journal, 36(4), 30-41.

16. Putri, B. R. T. (2017). Manajemen pemasaran. Denpasar: Universitas Udayana.

17. Semiawan, C. R. (2010). Metode Penelitian Kualitatif. Grasindo.

18. Shinta, A. (2011). Manajemen Pemasaran. Universitas Brawijaya Press.

19. Stewart, G. (2005). Sukses Manajemen Penjualan. ESENSI.

20. Sukotjo, H., \& Radix, S. A. (2010). Analisa Marketing Mix-7P (Produk, Price, Promotion, Place, Partisipant, Process, dan Physical Evidence) terhadap Keputusan Pembelian Produk Klinik Kecantikan Teta di Surabaya. Jurnal Mitra Ekonomi dan Manajemen Bisnis, 1(2), 216-228. 